\title{
Solidifying the White Domination through Racism and Slavery in Toni Morrison's Beloved
}

\author{
Thohiriyah \\ Faculty of Languages and Arts, Universitas Negeri Semarang, Indonesia \\ Email: thohiriyah@mail.unnes.ac.id
}

\begin{abstract}
Beloved is a novel written by American author, Toni Morrison. Through Beloved, Toni Morrison successfully depicts a heartbreaking phenomenon of slavery that happened in the USA in 1873. Morrison describes the phenomenon of dominance-submission interrelation patterns in a master-slave relationship. By using the concept of racism and slavery, the paper aims at scrutinizing how the whites perform racism and slavery to solidify their domination over the blacks. Besides, it is aimed at investigating the impacts of slavery and racism done by the whites which are experienced by the slaves. Library research and close-reading methods are employed to analyze the novel. Besides, the qualitative and contextual method which focuses on intrinsic and extrinsic elements is utilized. The result of the analysis shows that racism and slavery are major elements that solidify whites' domination over black slaves. In other respect, racism and slavery lead to great negative impacts for the black slaves. Excessive trauma and identity loss are the major impacts experienced by the slaves as the consequence of slavery and racism.
\end{abstract}

Keywords: dominance, slavery, racism, submission

\section{INTRODUCTION}

Morrison's Beloved (1987) focuses on the Black slaves' life. Sethe, Halle, Sixo, Paul D, Paul A, and Paul $\mathrm{F}$ are some characters of the black slaves in Beloved. They worked as slaves at Sweet Home, a plantation belonged to $\mathrm{Mr}$. Garner and his white family in Ohio. They often got terrible, insolent, and ferocious treatments from the Sweet Home family members who were all white while working as slaves at the Sweet Home. When Sethe was pregnant and about to have delivery, she planned to escape with her husband to Cincinnati. Sethe successfully managed her three children to go to Cincinnati before her escape. However, Sethe underwent a sexual abuse done by a white superior who belonged to Sweet Home family member. Halle witnessed her wife being raped before his eyes and it drove him crazy. Sethe finally gained freedom and lived in Cincinnati. However, the slave hunters who were working for Sweet Home still haunted her and her family. They found Sethe and her family in Cincinnati and intended to drag them back to Sweet Home as slaves. Sethe who did not want to surrender her children to the life of slavery then killed her children by slitting their throat. Death is simply a way out of slavery.

Beloved highlights heartbreaking slavery in the United States experienced by black slaves. Through the narration of slavery, Morrison enunciates the white domination over the black. Racism and slavery are the basis of the white domination concept in Beloved.

With regard to racism, Dijk (1991) states that racism is a complex social system in which there is a certain group that dominates other groups. The domination includes, not limited to, economic, socio-cultural aspects, and political hegemony which leads to negative impacts towards the groups being dominated. Historically, the race is categorized based on the physical appearance mainly a skin complexion. The difference in skin complexion leads to a human race 
taxonomy. This human race taxonomy is also influenced by the socio-cultural characteristics of the race. As white is considered as a group that possesses noble culture, the white race is socially considered as superior above all. White's superiority is often administered to legitimate oppression, exploitation, or extermination of other racial groups as those happened during Western imperialism, colonialism, holocaust, and slavery (Dijk, 1991).

Dealing with slavery in the United States, white poses as a superior master and the black as their slaves. White's superiority is demonstrated by dominating the black in the form of oppression and servitude. The relation pattern formed is a "master-slave" pattern. In this relation pattern, a master possesses great domination, while the slaves are emplaced in a "subordinate" position (Eyerman, 2004). In their subordinate position, slaves have no power and truly submit to the master. This relation pattern, according to Bateson (2007), is called "dominance-submission" relation. Risakotta $(2002 / 2003$, p. 125$)$ postulates that domination is the principle of subjecting and controlling individuals by exploiting them in terms of physical, cultural, religious, and thought in order to gain benefits in the form of economic benefits and to gain power.

Slavery causes a negative impact on the slaves. It triggers, for example, excessive trauma. Dealing with trauma, Eyerman (2004) theorizes that trauma caused by slavery occupies a position as a "collective memory", a memory of how one's identity is constructed. Slavery is a traumatic "retrospect" where Afro-Americans will always feel that they have been slaves and always feel African. Thus slavery has distinguished races where the black race will always occupy a low position and at the same time emplace the white race in the upper position who has the superiority to subdue slaves. The identity of the slaves which is formed by the traumatic experience on slavery is a means for the whites to establish their dominance over the downcast race, black people.

This paper, then, tries to investigate how white dominance is solidified through racism and slavery and scrutinize the impact of white domination to the black slaves.

\section{METHODOLOGY}

In analyzing Toni Morrison's Beloved, library research and close-reading methods are employed. The data are gained from the novel and from the supporting concepts which are compiled using the two methods. Qualitative method is generally administered to analyze the data. Furthermore, the contextual method is employed to conduct literary analysis. The contextual method focuses on intrinsic and extrinsic elements. Intrinsic elements emphasize the characters and major conflicts in the novel, while the extrinsic elements adopt the concept of racism and slavery.

\section{DISCUSSION}

White domination solidification is done through racism and slavery. Racism in Morrison's Beloved which is done by the white over the black is in the form of insolent treatment and discrimination. Meanwhile, the slavery practice is done by applying the concept of dominance-submission in the master-slave interrelation.

The insolent treatment which is done by the sadistic Schoolteacher, Mr. Garner's brother-in-law, to Sixo, one of the black slaves working at Sweet Home, is in the form of defamation. The Schoolteacher defames Sixo as a thief just because he is a black and slave, "You stole that shoat, didn't you?" (Morrison, 1987, p. 190). By vilifying Sixo stealing a shoat, Schoolteacher defines Sixo's identity as a thief. Sixo does not have the power to defend the identity of the thief he just received because "definitions belonged to the 
definers - not the defined" (Morrison, 1987, p. 190).

Referring to Morrison's notion above, it goes beyond doubt that the position of "definers" and "defined" is hierarchically classified based on the race. The definers belong to the white superior masters. Meanwhile, the "defined" is considered as the black, the inferior slave group. As a consequence of the hierarchical position, the black tends to be submissive to the white. Defamation addressed to Sixo proves that the white is racist. They do not need any proof and simply judge, "everything they touched was looked on as stealing" (Morrison, 1987, p. 190). The aforementioned quotation underlines the discriminative behavior as the white defines and judges someone as a thief just because he is a slave and black.

The discrimination performed by the White is shown by the Morrison's writing as follows.

"Even the educated colored: the long-school people, the doctors, the teachers, the paperwriters and the business man had a hard row to hoe. In addition to having to use their heads to get ahead, they had the weight of the whole race sitting there. You needed two heads for that. White people believed that whatever the manners, under very dark skin was a jungle. Swift unnavigable waters, winging screaming baboons, sleeping snakes, red gums ready for their sweet white blood" (Morrison, 1987, p. 190).

From the quotation above, it can be seen that black people are discriminated against by white people. White people believe black people do not deserve their respect. Everything done by the black people is considered as wild and ill manner, "White people believed that whatever the manners, under very dark skin was a jungle" (Morrison, 1987, p. 190). Morrison uses the metaphor "jungle" to describe how white people justify black people's manner. The manner justification is solely and subjectively based on the skin complexion, not based on the value of the manner promoted by the individual. From the aforementioned analysis, it can be said that Morrison wants the reader to see if the black slaves are submissive. Their submission is both in terms of their role as workers and also in terms of identity. The whites do not allow black slaves to create their own identity. Consequently, black slaves solely accept the identity constructed by whites.

In respect of dominance-submission in slave-master interrelation reflected in Beloved, whites impose their dominance by applying the convict-lease system in punishing the black slaves. In the convict-lease system, according to Charles, "black men were convicted of baseless crimes such as vagrancy or the intent to steal" (2005). In Beloved, white domination is reflected in their power in forcing the blacks to work for slavery in the Sweet Home. The black slaves will get inhuman punishment when they are suspected to do mistakes or even baseless crimes. The whites send the blacks to the prison or hang them on the trees, "Passed right by those boys hanging in the trees. One had Paul A's shirt on but not his feet or his head" (Morrison, 1987, p. 190). Through Sixo, for example, Morrison lets the readers notice that the racism system promoted by the whites is cruel and inhuman.

Racism and slavery, on the one hand, strengthen white domination. However, on the other hand, racism and slavery lead to deteriorative impacts for the Black slaves. Psychological destruction and identity loss are two considerable impacts experienced by black slaves. Psychological destruction is in the form of excessive trauma. The trauma suffered by black slaves is the result of insolent treatments committed by the white masters. Besides, white domination leads to slaves' identity loss.

In Beloved, great trauma is suffered by Sethe. Although Sethe successfully managed to escape from Sweet Home to Cincinnati with her family, she cannot merely forget the memory of being a slave in the Sweet Home. Her bad experience in Mr. Garner's 
plantation set a haunting trauma for her. Her traumatic memory of slavery suddenly appears whenever she sees or meets whites. Once she saw Mr. Bodwin, a white abolitionist who fought for her freedom, she strongly wanted to stab Mr. Bodwin. She did that because she cannot bear her trauma since Mr. Bodwin made her recalling her memory on her masters and the white slave hunter working for the Sweet Home.

Identity loss is elucidated through the character named Beloved. The emergence and disappearance of Beloved character in the story reflect the anomalies of identity and the existence of Beloved. When she came to 124 and was asked who she was, Beloved knew nothing. She did not know where she came from and who she was. The unclear identity about her strengthens the concept of corrupt identity or identity loss. In the master-slave interrelation, the slave is the one who is always being dominated by the masters. Masters' domination makes the slave loses their self-sovereignty and leads to the destruction of the individual identity. Everything that was experienced by the victims of slavery once again confirmed the dominance of white slave masters.

\section{CONCLUSION}

Morrison's novel entitled Beloved reveals that racism and slavery are potentially able to solidify white domination over black slaves. Insolent treatment and discrimination are major elements in racism, while "dominancesubmission" is the basis of slavery in Morrison's Beloved. The slave-master relationship is established based on the concept of dominance-submission. It is apparent that the "dominance" belongs to the whites, while the "submission" is performed by the black slaves. Black slaves often treated badly by the powerful whites. The whites impose their superiority to the slaves by forcing them to work in slavery. The slaves often get defamation and severe inhuman punishment for their baseless mistakes. Besides, through Beloved, Morrison also spots on the impacts of white domination through racism and slavery that is tragic trauma and identity loss.

\section{REFERENCES}

Bateson, G. (2007). Some Systematic approaches to the study of culture and personality. New York City: Council on Intercultural Relation.

Eyerman, R. (2004). Cultural Trauma: Slavery and the Formation of Afro American Identity. Cambridge: Cambridge University Press.

Morrison, T. (1987). Beloved. New York: Alfred A. Knopf, Inc.

Risakotta, A. B. (2002). Teori kekuasaan dari bawah. As cited in Renai, 2002/2003, p. 125.

Van Dijk, T.A. (1991). Racism and the Press. London: Routledge.

Wilson, Ch. E. Jr. (2005). Race and Racism in Literature. Westport: Greenwood Press. 